\title{
The Effect of Online Written Feedback through Social Media on Students' Writing
}

\author{
Rona Elfiza ${ }^{1}$, Aninda Sri Reszki ${ }^{1}$ and Dewi Nopita ${ }^{1}$ \\ ${ }^{1}$ Universitas Maritim Raja Ali Haji \\ email: ronaelfiza@umrah.ac.id \\ email: aninda.reszki@gmail.com \\ email: dewinopita@umrah.ac.id
}

\begin{abstract}
Writing is considered as a hard language skill for students. English teachers have been trying to find the effective way to enhance their students' writing skill. One of them is providing feedback in students' written work, also known as written Feedback. This article retrieved from the research on the effect of online written feedback through social media on students' writing in SMAN 4 Tanjungpinang. This research aims to find out the effect of Online Written Feedback on students' writing skill through social media Facebook at SMAN 4 Tanjungpinang. A pre-experimental design with one group pre-test-post-test was used in this research. There were 30 eleventh grade students of SMAN 4 Tanjungpinang as the sample of the research. This research used written assignment as its instrument. A pre-test is administered at the beginning of the research and followed by providing online written feedback on students' writing personal letter as the treatment. A post-test was also conducted after the treatment. The pre-test and post test scores were analysed by using a paired sample t-test to answer the research hypothesis. This research showed that online written feedback did not significantly affect the students' writing skill in SMAN 4 Tanjungpinang. There was a difference between the mean score of pre and post-test, from 83.07 to 85.70 , but it was not significantly.
\end{abstract}

Keywords: Online Written Feedback, Social Media, Writing Skill

\begin{abstract}
Abstrak
Menulis merupakan keterampilan bahasa yang sulit bagi siswa. Para guru bahasa Inggris telah mencoba menemukan cara yang efektif untuk meningkatkan keterampilan menulis siswa. Salah satunya adalah dengan adanya feedback terhadap tulisan siswa yang lebih dikenal dengan istilah feedback tertulis. Artikel ini ditulis berdasarkan penelitian tentang pengaruh penggunaan feedback tertulis secara online melalui media sosial terhadap kemampuan menulis siswa di SMAN 4 Tanjungpinang. Penelitian ini bertujuan untuk menemukan efek dari feedback tertulis online terhadap keterampilan menulis siswa melalui media sosial facebook di SMAN 4 Tanjunpinang. Pra-eksperimen satu grup dengan pre-test post-test adalah desain yang digunakan dalam penelitian ini. Terdapat 30 siswa kelas XI SMAN 4 Tanjungpinang sebagai sampel penelitian ini. Instrument penelitian ini menggunakan tugas menulis siswa. Pre test di administrasikan di awal penelitian dan diikuti dengan pemberian feedback tertulis secara online pada hasil menulis surat pribadi siswa
\end{abstract}


sebagai treatment. Post test juga di administrasikan pada akhir penelitian. Skor pre dan post test lalu di analisis menggunakan uji paired sample t-untuk menjawab hipotesis penelitian. Kemudian uji paired sample $t$ juga di administrasikan untuk menguji hipotesis penelitian. Hasil dari penelitian menunjukan bahwa feedback tertulis secara online tidak memberikan efek yang signifikan pada keterampilan menulis siswa di Tanjungpinang. Walaupun terdapat perbedaan nilai rata-rata antara nilai rata-rata pre dan post test dari 83.07 ke 85.70 namun, peningkatan skor tidak berbeda secara signifikan.

\section{Kata Kunci: Feedback tertulis online, Media sosial, Keterampilan menulis}

\section{INTRODUCTION}

Students' attainment of communicative competence is the goal of language teaching in high schools in Indonesia (Setyono, 2014), in which students are expected to master the knowledge, abilities, as well as skill for communication (Yassi, 2018). The focus of the usage of target language will be shifted to the fluency instead of merely on the accuracy. Students are expected to be able to communicate orally and written by using the target language in daily life. In fact, most of students in senior high school in Indonesia especially in SMAN 4 Tanjungpinang admitted that they do not even have enough vocabulary and great understanding of the grammar rules which make them hard to communicate their target language freely. It may affect the attainment of basic skills and also lead to the writing apprehension or writing anxiety (Challob et al., 2016). It ends up with the poor writing performance and do not achieve the learning goal, which based on the syllabus that is focused on social function, generic structure, and language features.

Writing is also considered as the hardest one among those four skills even for native speaker, (Richards \& Renandya, 2002). This skill is not only about conveying what is on writer's mind in readable form, yet it is also about organizing the ideas well, constructing a good sentence without making any grammatical error, using the punctuation correctly, and selecting the preferences vocabulary. It is also including the process of thinking and creative skill inside, so that the writer's thought or idea may be wellreceived by the reader.

Since years ago many researchers or teachers have been trying to find the effective way to improve the students' writing. One of the efforts done is by providing feedback on students' work, also known as written feedback. written feedback has been defined by Mack (2009) as any error corrections, comments, or questions that are written on students' assignment. Feedback has been considered as one of the essential process for the improvement of students writing skill (Hyland \& Hyland, 2001). It contains such useful information regarding students' work or performance which may facilitate the improvement of students and provide the opportunities of an interaction between students and teacher (Hyland \& Hyland, 2006). Written feedback may come in various forms such as form-focus correction which only focus on the grammar usage of students, content feedback which focus on content quality and organizational features, and integrated feedback as the combination of form-focus and content-related feedback. 
However, the effectiveness of providing feedback on students' work still become the controversial issue, Truscott, (2007) finds that feedback may lead to the negative results, as feedback could decrease the motivation of students and make them feel under the pressure when their work filled with errors and written corrections on it.

In the process of giving feedback teachers spend numerous hours identifying and correcting their students' error, but most of the time the students do not even bothered to read or rectify it. It may because of the illegibility of the teacher's handwriting and also may because of the insufficient information they received from the correction, which leave students confuse all the time. Teacher usually finds students asking about what actually has been written on their paper, how could something that they have made consisting an error. Students tend to get a lot of questions when the feedback is already given, but since the feedback given is in the conventional pen and paper there were no further information about the errors that have been committed or any better suggestion of their work which made them confused and finally ignored the given feedback.

Recently, teachers use social media as one of the learning tool to facilitate the students learning. Boyd \& Ellison, (2008) define social media as websites which provide some features such a profile creation and visibility of relationships between the users. Some of previous related studies regarding online feedback found that EFL learners tend to have positive attitude toward online feedback. It is in line with the fact that students nowadays are fascinated with gadgets, internet, and especially social media, it has become a common or even an essential thing for them, the flexibility and the durability of the use of internet also become a plus point for the teacher to make use of it. Furthermore, feedback given on social media may also reduce the students' writing anxiety, as stated by (Hussin et al., 2015) that, the contribution of online environment to the students' writing anxiety in the writing process such as drafting, revising, editing is learners may benefit from feedback both from teachers and peers through such activities, as they can do the processes freely and personally in such environment.

There have been some researches conducted by researchers which related to the use of online written feedback. The first related research had already been conducted by Razagifard \& Razzaghifard, (2011) the result of the research showed that students who received online corrective feedback did a better performance to those without feedbacks. Then, Yoke et al., (2013) have investigated the use of online Feedback which compared between the use of Online and conventional feedback on EFL learners' writing. It showed that online feedback is potentially useful to be integrated into teaching and learning activities. The result of the interview showed that students have more preference in receiving online feedback via e-mail than conventional pen and paper. The third related research had already been conducted by Sain et al, (2013). This research showed that online feedback did improve the ESL learners' writing skill. The result is the learners' writing improved from the first draft into its second draft.

However, in a study on the use of corrective feedback in a computer assisted practice exercise, it found that corrective feedback was not really affect the students' performance (Adams \& Strickland, 2011). In addition, Ali, (2011) in his study about the motivational level of learners in learning with and without computer, also 
found that there was no significant different level of motivation between learning with or without computer.

Based on the issues above, the researcher was interested in conducting research to know the effect of online written feedback through social media on students' writing in SMAN 4 Tanjungpinang. By knowing the effect of online written feedback through social media on students' writing, it can be considered whether the online written feedback through social media can be used as one of ways in teaching writing or not.

\section{METHOD}

The design of this research was Preexperimental. According to Sugiyono, (2011), this type of design is not the real experiment yet, since there may be an extraneous variable that may be involved in the formation of dependent variable itself. It is because in this type of research there is no control variable. Moreover, the sample is chosen with non-random assignment. Then, according to Creswell, (2014), there are four types of group design in Preexperimental research. (1) one case study, (2) one group pretest-posttest design, (3) Static Group Comparison or Posttest Only with Non Equivalent Groups, (4) Alternative Treatment Posttest-only with Nonequivalent Groups Design.

In this research, the researcher used Pre-experimental design, with one group pretest-posttest design. XI MIPA 3 had become the chosen class to participate on this research. This research is focused to one group only which receive the treatment to found out the effect of the independent variable towards the dependent variable. Then researcher analyzed from the data obtained from the pre and post-test score of the group.

This research used purposive sampling technique. One class of 11th grade of SMAN 4 Tanjungpinang had become the selected class as the sample of the research. 30 students out of 40 students were agreed to participate in this research. All of the students were given the online written feedback on their written work during the process of their writing.

Writing assignment was used as the instrument of this research. The students were required to write their own personal letter based on its correct social function, generic structures, and its language feature. Then the students' written product will be graded and evaluated based on those aspects (social function/purpose, generic structure, language feature). They were asked to write a letter related to theirs or others' recent activities during 2020 pandemic. Rating scale of this instrument can be seen in appendix 1 .

In order to find the effect of using online written feedback through social media on students' writing in personal letter, the researcher checked the normality of the data first. The researcher used Kolmogorov Smirnov to test the normality of the data. Then to test the hypothesis, the researcher used paired sample t-test. This test compare the mean of the two data to find out whether there is a significant effect of the implementation of online written feedback on students' writing.

\section{FINDING AND DISCUSSION}

The data of this research was collected by administering a written assignment test. The first test was a pre-test which done before the treatment applied to the students, which was intended to know students' writing skill before the treatment given. The 
result of the pre-test showed that actually the students' writing ability was considered in a very good ability by analysing the mean of pre-test scores, but almost all of them got difficulty in constructing a sentence with appropriate grammatical and word usage.

After administering the pre-test, the researcher gave the treatment to the students by giving the online written feedback on their writing performance. The treatment was given by highlighting, underlining, and commenting on the error committed by the students via online by using social media Facebook and Ms. Word as the media to provide the online feedback. After the treatment given, the researcher handed back the students' work and asked them to rectify their work and submitted it again via personal message messenger. Soon as the treatment was finished the researcher administered the post-test. The researcher asked them to write the same writing assignment with the same instruction to find out the result of students' writing skill after being given the online written feedback on their writing. The result of pre-test and post-test of one group experimental were presented on the table below:

Table.1: The Result of Pre-test and Post-test of one Group Experimental

\begin{tabular}{|l|l|l|}
\hline Score & $\begin{array}{l}\text { Pre- } \\
\text { test }\end{array}$ & Post-test \\
\hline Mean & 83.07 & 85.70 \\
\hline Median & 85.50 & 86.00 \\
\hline $\begin{array}{l}\text { The Highest } \\
\text { Score }\end{array}$ & 94 & 95 \\
\hline
\end{tabular}

\begin{tabular}{|l|l|l|}
\hline $\begin{array}{l}\text { The Lowest } \\
\text { Score }\end{array}$ & 65 & 69 \\
\hline
\end{tabular}

The table above showed that the students' results before and after the treatment given in general description, without knowing to what extent did the students make an improvement or even what was the common error made by the students during the writing process. There are 3 components of the personal letter which become the estimation of their writing. They are purpose, the text structure, and its language feature.

For the detail description of the comparison of each extent between pre-test score and post-test score may be seen on the table below:

Table.2: The percentage Score of Each Writing Components of Pre-test and Posttest Score

\begin{tabular}{|l|l|l|l|}
\hline Test & Purpose & $\begin{array}{l}\text { Text } \\
\text { Structure }\end{array}$ & $\begin{array}{l}\text { Language } \\
\text { Feature }\end{array}$ \\
\hline Pre-test & $81.9 \%$ & $93.3 \%$ & $75.4 \%$ \\
\hline Post Test & $78.7 \%$ & $98.4 \%$ & $80.2 \%$ \\
\hline
\end{tabular}

Table 2 above shows any improvement that occurred during the process of first writing assignment to the final assignment. It can be seen from the table that a reduction was occurred on the purpose of the text from $81.90 \%$ to $78.70 \%$ which is decreased about $2 \%$. In contrast the students showed better performance on text structure and language feature with the increased number of score between pre-test compared to post-test which is about 5\% both for structure of the text and the language feature as well. Then, the students seemed did a better job on the structure of 
the text with error $2 \%$ only after the online written feedback was given.

In this research, researcher used Kolmogorov Smirnov to test the normality of the data. A normality test was also run as the pre-requisite of the paired sample T-test to make sure that the data come from a normal distribution.

Table 3: Test of Normality

\begin{tabular}{|c|c|c|c|}
\hline \multicolumn{4}{|c|}{ One-Sample Kolmogorov-Smirnov Test } \\
\hline & & pretest & posttest \\
\hline N & & 30 & 30 \\
\hline \multirow[t]{2}{*}{ Normal Parameters ${ }^{a, b}$} & Mean & 83.07 & 85.70 \\
\hline & Std. Deviation & 9.303 & 7.666 \\
\hline \multirow[t]{3}{*}{ Most Extreme Differences } & Absolute & .139 & .164 \\
\hline & Positive & .120 & .118 \\
\hline & Negative & -.139 & -.164 \\
\hline Kolmogorov-Smirnov Z & & .759 & .896 \\
\hline Asymp. Sig. (2-tailed) & & .612 & .398 \\
\hline
\end{tabular}

Table 3. Showed that the result of the normality test of pre and post-test scores. The significant value of both of the scores can be seen on Asymp. Sig. (2-tailed) Table Table 3 shows that 0.612 for the pre-test and 0.398 for the post-test score. Both of the sig value is $>0.05, \mathrm{H} 0$ is accepted and it means both of the data come from a normal distribution.

To test the hypothesis, the researcher used paired sample t-tes. This test compare the mean of the two data to find out whether there is a significant effect of the implementation of online written feedback on students' writing by analysing the pre and post-test scores of the students' writing performance. In this research the researcher used statistical software SPSS Statistics 21 to analyse the data. A paired sample t-test was run and the results are shown on those tables below.

Table. 4: Paired Sample Statistic Paired Samples Statistics

\begin{tabular}{|ll|r|r|r|c|}
\hline & & Mean & \multicolumn{1}{|c|}{$\mathrm{N}$} & Std. Deviation & $\begin{array}{c}\text { Std. Error } \\
\text { Mean }\end{array}$ \\
\hline Pair1 & pretest & 83.07 & 30 & 9.303 & 1.699 \\
& posttest & 85.70 & 30 & 7.666 & 1.400 \\
\hline
\end{tabular}

Table 4 shows the descriptive value of each variable in a paired sample t-test. The pre-test got 83.07 as the mean score from 30 students as the participants and got 9.303 as the standard deviation with 1.699 as the standard error. In another hand, the post-test got 85.70 as the mean score from 30 participants as well and got 7.666 as the standard deviation with 1.400 as the standard error. It clearly shows that the mean score of the post-test is higher than the pre-test score. It shows that there were any improvement between those scores, but this table does not clearly explain yet whether the improvement between those scores was significant or not. Then, the correlation between the two variables in paired sample t-test can be seen in table below:

Table. 5: Paired Sample Statistics

Paired Samples Correlations

\begin{tabular}{|l|r|r|c|}
\hline & \multicolumn{1}{|c|}{$\mathrm{N}$} & Correlation & Sig. \\
\hline Pair 1 pretest \& posttest & 30 & .562 & .001 \\
\hline
\end{tabular}

The table above shows the correlation between the two variables in paired sample t-test. The result shows that the correlation between those two variables is 0.562 with 0.001 as the significant value which is showed that the correlation between the mean of pre and post-test is strong and significant.

In order to find out whether online written feedback has significant effect on students' writing achievement, a paired sample t-test was run as shown on table 6 below. 
Table. 6. Paired Sample t-test.

\begin{tabular}{crc}
\hline Pairs & $\mathrm{t}$ & sig-(2-tailed) \\
\hline Pre and Post test & -1787 & .084
\end{tabular}

The result of paired sample t-test run by SPSS 21 showed the significant value as 0.084 with the significant level 0.05 , as the significant value $0.084>0.05$ which indicates that there is no signifficant different on students' writing performance before and after the implementation of online written feedback through social media facebook. Although the findings also show that the students have made an improvement in some aspects of the writing which are structure of the text and its language features which include vocabulary, grammar, and spelling, in another hand, a degression was occurred on the purpose of the text.

Consequently, the result seem that is not in line with another studies that support online feedback. First, Mason and Bruning, (2001 summarized that the researcher could present immediate feedback on learners' responses, one to one response. unlike in the classroom setting environment, where adequate feedback is hard to give because it will be constrained by the limitation of the time. Next, research had already been conducted by Razagifard \& Razzaghifard, (2011) the result of the study showed that students who received online corrective feedback did a better performance to those without feedbacks. Then,Sain et al., (2013); Yoke et al., (2013) Hussin et al., (2015) found that online feedback is potentialy useful to be used in the process of teaching and learning of academic writing.

The ineffective of online feedback on students' writing in SMAN 4 Tanjungpinang could be explained by some reasons. First, this research conducted during the covid 19 in 2020. There was no teaching process in a school; Instead, the learning process was conducted completely in an online environment. The researcher believes that the implementation of online learning should be integrated with conventional learning activity in classroom, especially in the teaching of writing where the teacher is supposed to guide and watch the process of creating their own writing product. This case is in line with on Hyland \& Hyland, (2006). The feedback may be ineffective when the students misuse or ignore comments or suggestions given by the teacher when revising drafts, in this case, the students were tended to ignore the note or comment given at the bottom of the paper which contained some suggestion regarding their content of the letter written in English, the reason was because the students admitted that they did not even understand what was written on the comment since it was written in English, then they tended to ignore the note and seemed to focus more on text structure and language feature errors which were highlighted and coded on sentences which errors occurred. Then, Adams \& Strickland, (2011) found that corrective feedback was not really affecting the students' performance.

Another reason may be because of the infeasible devices that some of the students have. Not all of the students have their own personal computer, as the process of drafting was conducted by using Ms. Word. some of them still had some troubles with it. It seems like not all the students are ready to have such online learning. moreover, the students' motivation or interest in learning English need to be taken into account, most of the students found to be less interested in English and have a low motivation on learning which made the process of online learning become harder because most of them did not want to find 
out any further about the error committed, some of the students were really interested in receiving feedback as evaluation on their learning progress it can be seen from their enthusiastic in discussing their error to the researcher, some of them were not really bother with the feedback given as the most important thing was the score that they got. The students who are less motivated will not take the feedback in a serious way, they may just simply delete the sentence which contained errors to avoid the issues raised or simply change the sentence which has been suggested by the researcher, thus a learning process hard to occur. Ali, (2011) found that motivational level of learners in learning with and without computer, also found that there was no significant different level of motivation between learning with or without computer.

In brief, it can be concluded that the result of the effect of online written feedback through social media on students' writing in SMAN 4 Tanjungpinang. This research was clearly in accordance with some related theories. Based on the discussion above, there is no signifficant different on students' writing performance before and after the implementation of online written feedback through social media facebook. Although there is improvement in some aspects of the writing which are structure of the text and its language feature, but it is not significant.

\section{CONCLUSION}

Based on the data analysis described above, the conclusion can be drawn that the using of online written feedback through social media does not really give significant effect on students' writing in SMAN 4 Tanjungpinang. There are two factors that caused the using feedback is not significant.
First, there was no teaching process in a school because this research conducted during the covid 19 in 2020 the learning process was conducted completely in an online environment. The implementation of online learning should be integrated with conventional learning activity in classroom Second factor related to devices that some of the students have. Not all of the students have their own personal computer, as the process of drafting was conducted by using Ms. Word. Some of them still had some troubles with it. It seems like not all the students are ready to have such online learning.

\section{REFERENCE}

Adams, R. H., \& Strickland, J. (2011). The Effects of Computer-Assisted Feedback Strategies in Technology Education: A Comparison of Learning Outcomes. Journal of Educational Technology Systems, 40(2), 211-223. https://doi.org/10.2190/et.40.2.i

Ali, K. (2011). Communication, Motivational Attitudes of ELT Students Towards using Computer for Writing and Communication. Teaching English with Technology, 11(3), 37-53.

Boyd, Danah M; Ellison, N. (2008). Social Network Sites: Definition, History, and Scholarship. Journal of ComputerMediated Communication, 210-230.

Challob, I., Bakar, N. A., \& Latif, H. (2016). Collaborative Blended Learning Writing Environment : Effects on EFL Students 'Writing Apprehension and Writing Performance. English Language Teaching, 9(6), 229-241. https://doi.org/10.5539/elt.v9n6p229

Creswell, J. W. (2014). Research Design: Qualitative, Quantitative, and Mixed 
Methods Approaches (Fourth Edi). SAGE Publications, Inc.

Hussin, S., Abdullah, M. Y., Ismail, N., \& Yoke, S. K. (2015). The Effects of CMC Applications on ESL Writing Anxiety among Postgraduate. English Language Teaching, 8(November 2016), 167-172. https://doi.org/10.5539/elt.v8n9p167

Hyland, F., \& Hyland, K. (2001). Sugaring the pill Praise and criticism in written feedback. Journal of Second Language Writing, 10, 185-212.

Hyland, K., \& Hyland, F. (2006). Feedback on Second Language Students' writing. Cambridge University Press.

Mack, L. (2009). Issues and Dilemmas: What Conditions are necessary for Effective Teacher Written Feedback for ESL Learners? Polyglossia, 16.

Mason, B. J., \& Bruning, R. (2001). Providing feedback in computer-based instruction: What the research tells us. Retrieved February, 15(January 2001), 2007.

Razagifard, P., \& Razzaghifard, V. (2011). No Title. Teaching English With Technology, 11(2), 1-17.

Richards, J. C., Renandya, W. A. (2002). Methodology in Language Teaching An Anthology of Current Practice. Cambridge University Press.

Sain, N., Yoke, S. K., Hidayah, N., Kristen, U., \& Wacana, S. (2013). Utilising Email for Online Corrective Feedback in Academic Writing among Utilising E-mail for Online Corrective Feedback in Academic Writing among ESL Undergraduates. March.

Setyono, B. (2014). Approaches in Teaching Writing Designed by High School English Teachers in Indonesia. International Journal of Sciences: Basic and Applied Research, 14, 477494.
Sugiyono. (2011). Metode Penelitian Pendidikan Pendekatan Kuantitatif, Kualitatif, dan $R \& D$. Alfabeta.

Truscott, J. (2007). The effect of error correction on learners' ability to write accurately. Journal of Second Language Writing, 16, 255-272. http://dx.doi.org/10.1016/j.jslw.2007.0 6.003

Yassi, A. H. K. (2018). Syllabus Design For English Language Teaching. Prenadamedia Group.

Yoke, S. K., Hidayah, N., Sain, N., \& Nawi, S. md. (2013). The Use of Online Corrective Feedback in Academic Writing by L1 Malay. English Language Teaching, 6, 175180.

Yoke, S. K., Sain, N., Hidayah, N., Kristen, U., \& Wacana, S. (2013). The Use of Online Corrective Feedback in Academic Writing by L1 Malay. English Language Teaching, 6(July 2014), 175-180. https://doi.org/10.5539/elt.v6n12p175

\section{APPENDIX 1 Rating scale}

\begin{tabular}{|c|c|}
\hline & Purpose \\
\hline $30-27$ & EXCELLENT \\
\hline & $\begin{array}{l}\text { GOOD: fully expressed the } \\
\text { writing feeling - provide clear } \\
\text { information - describe the } \\
\text { writer's or other's recent } \\
\text { activities in detail. }\end{array}$ \\
\hline $26-22$ & $\begin{array}{l}\text { GOOD TO AVERAGE: show } \\
\text { the writers' feeling - provide an } \\
\text { adequate clear information - } \\
\text { provide the writer's or other's } \\
\text { recent activities but may be } \\
\text { missing some detail. }\end{array}$ \\
\hline $21-17$ & $\begin{array}{l}\text { FAIR TO POOR: not really } \\
\text { show or understand the feeling } \\
\text { toward the reader - provide the }\end{array}$ \\
\hline
\end{tabular}




\begin{tabular}{|c|c|}
\hline \multirow[t]{2}{*}{$16-13$} & $\begin{array}{l}\text { information but not really clear } \\
\text { - provide a little or general } \\
\text { description of activities not into } \\
\text { detail. } \\
\text { VERY POOR: no understanding } \\
\text { of the relationships between the } \\
\text { two characters - no/unclear } \\
\text { information - do not provide or } \\
\text { describe any activities. }\end{array}$ \\
\hline & $\begin{array}{l}\text { Structure of the text; complete } \\
\text { and sequential component }\end{array}$ \\
\hline $30-27$ & $\begin{array}{l}\text { EXCELLENT TO VERY } \\
\text { GOOD: Letter is complete with } \\
\text { all required elements - the } \\
\text { elements are in the sequential } \\
\text { order. }\end{array}$ \\
\hline $26-22$ & $\begin{array}{l}\text { GOOD TO AVERAGE: Some } \\
\text { personal letter elements may be } \\
\text { missing - some of the elements } \\
\text { of the letter are not in sequential } \\
\text { order. }\end{array}$ \\
\hline $21-17$ & $\begin{array}{l}\text { FAIR TO POOR: Most personal } \\
\text { letter elements out of place or } \\
\text { missing - almost all of the } \\
\text { components are not in } \\
\text { sequential order. } \\
\text { VERY POOR: Improper form is } \\
\text { used - there's no sequential } \\
\text { order of the letter's components. }\end{array}$ \\
\hline & $\begin{array}{l}\text { Language features; grammar, } \\
\text { vocabulary, spelling }\end{array}$ \\
\hline $40-35$ & $\begin{array}{l}\text { EXCELLENT TO VERY } \\
\text { GOOD: use appropriate } \\
\text { grammatical form - effective } \\
\text { word choice and usage - } \\
\text { provide correct spelling. }\end{array}$ \\
\hline $34-23$ & $\begin{array}{l}\text { GOOD TO AVERAGE: there } \\
\text { are some inappropriate } \\
\text { grammatical forms - occasional } \\
\text { word/idiom form, choice and } \\
\text { usage but meaning not obscured } \\
\text { - occasional error of spelling }\end{array}$ \\
\hline
\end{tabular}

\begin{tabular}{|l|l|}
\hline $22-15$ & $\begin{array}{l}\text { FAIR TO POOR: major } \\
\text { problem on the use of } \\
\text { grammatical form - frequent } \\
\text { error of word/idiom form, } \\
\text { choice, usage - frequent errors } \\
\text { of spelling } \\
\text { VERY POOR: virtually no } \\
\text { mastery of the usage of } \\
\text { grammatical form - little } \\
\text { knowledge of English } \\
\text { vocabulary - dominated by } \\
\text { errors of spelling. }\end{array}$ \\
\hline
\end{tabular}

